Eduvest - Journal of Universal Studies

Volume 2 Number 1, January 2022

p- ISSN 2775-3735 e-ISSN 2775-3727

\title{
REVITALIZATION OF LOCAL WISDOM (LUBUK PROHIBITION) IN MAQASHID AL-SHARIA'AHREVIEW OF THE WELFARE OF THE MUSLIM COMMUNITY
}

\author{
Nawir Yuslem, Nurhayati , Elwardi Hasibuan \\ North Sumatra State Islamic University, Indonesia \\ Email: nawir_yuslem@uinsu.ac.id,nurhayati@uinsu.ac.id, \\ elwardihasibuan17@gmail.com
}

\begin{tabular}{|c|c|}
\hline ARTICLE INFO & ABSTRACT \\
\hline $\begin{array}{l}\text { Received: } \\
\text { December, 26th } \\
2021 \\
\text { Revised: } \\
\text { January, } 17^{\text {th }} \\
2022 \\
\text { Approved: } \\
\text { January, } 18^{\text {th }} \\
2022\end{array}$ & $\begin{array}{l}\text { Lubuk prohibits one of the local wisdoms of the people of } \\
\text { Mandailing Natal Regency in environmental utilization. So far, } \\
\text { the pits of prohibition have been managed naturally and } \\
\text { traditionally, considering the large amount of damage caused } \\
\text { by illegal miners. To anticipate more fatal damage, } \\
\text { institutional revitalization is needed. The purpose of this study } \\
\text { is to analyze the management of lubuk prohibition in realizing } \\
\text { maqashid sharia and its role in improving the welfare of } \\
\text { society. This research is a qualitative research with an } \\
\text { ethnographic approach and uses a case study method. Sources } \\
\text { of research data were obtained through in-depth interviews } \\
\text { with key informants, namely Government Officials, Customary } \\
\text { Leaders, Lubuk Ban Managers, Community Leaders and Naposo } \\
\text { Nauli Bulung and other informants who understand and are } \\
\text { related to this research. Another method used to support the } \\
\text { results of interviews in informal FGD forums is field observation } \\
\text { and documentation. The results showed that the management } \\
\text { practice of Lubuk Ban in Mandailing Natal Regency has } \\
\text { changed into a new, more rational format with management } \\
\text { based on religious beliefs (Religious/Islamic). }\end{array}$ \\
\hline KEYWORDS & Local Wisdom, Welfare, Muslim Community \\
\hline c) (†) (2) & $\begin{array}{l}\text { This work is licensed under a Cre } \\
\text { Attribution-ShareAlike } 4.0 \text { International }\end{array}$ \\
\hline
\end{tabular}

\section{INTRODUCTION}

Mandailing Natal Regency, part of the North Sumatra Province which is inhabited by the majority of the Mandailing tribe, has the local wisdom of Lubuk Ban in Nawir Yuslem, Nurhayati , Elwardi Hasibuan. (2022). Revitalization of Local Wisdom (Lubuk Prohibition) In Maqashid Al-Sharia'ah Review of the Welfare of the Muslim Community. Journal Eduvest. Vol

How to cite: 2(1):116-120

E-ISSN: 2775-3727

Published by: https://greenpublisher.id/ 
almost all of its villages, which is a form of river flow management carried out by the community in public waters in their neighborhood to generate economic benefits. The results obtained from the bottom of the prohibition are used for various village development purposes that are beneficial to the whole community in order to realize the common good (Mutti, Yakovleva, Vazquez-Brust, \& Di Marco, 2012) (Yousfi, 2014). those who dig rivers looking for gold cause water pollution (Unlicensed Gold Mining (PETI) (Harwell, 2011), logging and use of forest areas for plantations causes environmental damage, in addition to policy makers who are not environmentally aware of local wisdom in this prohibition (Meadows \& Randers, 2012). So that the damage to the environment and nature is clear as a result of human actions that are very excessive in exploiting natural resources (Dominguez \& Benessaiah, 2017).

The National Disaster Management Agency (BNPB) recorded 2,925 disasters in Indonesia during 2020, including 1,065 flash floods and 572 landslide cases. For the North Sumatra Province in 2020 there have been 172 disasters, in Mandailing Natal Regency the damage to the river is not only physical but the ecosystem is also damaged. This makes the life of the people who are completely deprived worse, there is an increase in poverty of $9.18 \%$ of the total population of 489,569 people, because the source of income and productivity of land is reduced, making people's purchasing power low, resulting in a slowdown in economic growth. Whereas the community business sector which gives the most dominant role is the largest contributor to the Gross Regional Domestic Product (GRDP) of Mandailing Natal Regency, namely; agriculture, forestry and fisheries sectors (Lacasse, Lambert, \& Khan, 2017) (Altenburg \& Pegels, 2012).

The biggest consequence that may occur is in the form of social conflict or riots, namely mass movements that are destructive to the social order that has been well developed in the community as a form of community disappointment over economic inequality on the one hand and jealousy over the omission of policy makers on the other. In the midst of fears of a disaster occurring, there are many ways that can be done, one of which is to revitalize the pit of prohibition in Mandailing Natal (Cooke et al., 2016).. Revitalization in this paper means increasing and optimizing the role of the management of the forbidden pit because many are resistant (Weiss, 2021) (McClanahan, Allison, \& Cinner, 2015). It should be noted that the management and maintenance of natural resources from the point of view of Islamic Shari'ah, which is based on the principle of eco-efficiency (do not damage the ecosystem, take efficiently in thinking about the sustainability of natural resources) (Hashim, 2014). The benefits obtained in the management of the forbidden pit as a form of river utilization in reducing environmental damage for improving the community's economy from the point of view of Islamic law through the understanding of maqashid al-syari'ah are absolutely necessary in order to realize the benefit of humans in the world and in the hereafter.

\section{RESEARCH METHOD}

This research is a qualitative research and this research is a field research with an ethnographic approach. Ethnography was chosen to obtain an in-depth description and analysis of the culture and local wisdom of the community based on field research by observing and interviewing them and other related people.

\section{RESULT AND DISCUSSION}

The results of this study indicate that the management of lubuk prohibition is related to the objectives of Islamic law (maqashid al-syari'ah), namely maintaining 
environmental ecosystems and strengthening the existence of religious activities, such as the construction of houses of worship and madrasas. Lubuk prohibition is a form of area management or natural resources (rivers/fisheries) based on religion, because Islam encourages humans to conserve and manage natural resources. As caliphs, humans can take advantage of natural resources to meet their needs. To understand the meaning of syar'i in the provisions and regulations regarding the management of natural resources (lubuk prohibition), an understanding is used through maqashid al-syari'ah which is a method of understanding the purposes of syara' both contained in the Qur'an and Sunnah.

The concept of environmental management and maintenance from the point of view of Islamic law needs to be considered because environmental problems and natural resources are very urgent and closely related to the benefit of human life. In the view of Islam, humans are a monodual and monopluralist creation of God. Therefore, the economy as part of human life is not only physical, but also non-physical. Economics finds not only physical prosperity, but also spiritual prosperity (Campbell, 2021).

Sharia economics as a manhaj al-hayah (system of life) departs from the awareness of the teachings of Islam itself which is full of values, the value in sharia economics is economic morals (ethical economics). As a sharia economic system, it has a role that does not only have halal legislation. More than that islamic economics as a science seeks to respond to economic problems and human behavior in the sharia paradigm.

'Alal al-Fâs as quoted by Ahcene Lahsasna defines maqâșid al-syarî'ah as the goal and secret behind each sharia law. Maqâșid al-syarî'ah aims to protect the interests of mankind and prevent evil in all circumstances, and is committed to realizing benefits for the wider community by encouraging virtue and preventing evil. Imam al-Gazali in his book al-Mustașfâ and Imam ash-Syâtịî in his book al-Muwâfaqât categorizes maqâșid ash-syarî'ah into 5 (five) goals, namely protecting religion (hifz ad-dîn), protecting souls (hifz an-nafs), guarding reason (hifz'aql), guarding offspring (hifz an-nasl) and guarding property (hifz al-mâl). These five elements are very fundamental and comprehensively cover human life, so they are often referred to as al-kulliyah al-khamsah (5 comprehensive aspects), so that damage to just one aspect will have negative implications.

Yusuf al-Qardawi (L.1245 H/1926 AD) in his book, Rieâyat al-Bîee ah fî̀ Syarî̀at alIslâm, that Islam places environmental preservation as the basis for maintaining the main goals of religion (al-darûriyyât al-khams). Simply put, the environment is a prerequisite for realizing the main goals of religion (van Huis \& Oonincx, 2017). First, protecting the environment is the same as hifz al-dn, meaning that all efforts to protect the environment are the same as maintaining religion, because the sin of polluting the environment is the same as tarnishing religious substance, which indirectly negates human existence as khalfah fi al-ard. Therefore, man should not forget that he was appointed as caliph because of the power of Allah swt. on his earth (Cooper, 2019)(Shue, 2014). Deviant actions related to the environment will result in misery for the next generation. Efforts to maintain generation continuity are reflected in the teachings and recommendations to unite and build solidarity, which is applied concretely in maintaining all forms of exploitation of sources of sustenance that are the right of future generations (Bariah, 2018).

Fourth, protecting the environment is the same as taking care of ifz 'aql, only people who have no sense who are not burdened with protecting and preserving the environment. Efforts to maintain the continuity of human life will not work unless the mind is guarded, so that if there are humans who do damage to the environment, then the human has lost his mind. Because it is not appropriate for the behavior of drunkards (people who have 
lost their minds) to be applied in the pattern of interaction with the environment. Because when the role of reason has been abolished, humans will never understand what is right and what is false.

Fifth, protecting the environment is the same as hifz al-mâl. Allah swt., has made wealth as a provision in human life on earth. Wealth is not only money, gold, and gems, but everything that is needed by humans, such as plants, animals, water, air, and all that is on and in the bowels of the earth is an infinite wealth, given by God for human needs.

\section{CONCLUSION}

The management of lubuk prohibition in Mandailing Natal Regency can last for decades after undergoing a change from management based on animistic beliefs into a new, more rational format based on religious beliefs (Religious/Islamic), based on 3 main things, namely: (a) Value of benefit, community cohesiveness and management accountability, (b) the value of compassion and unity based on the Dalihan Na Tolu philosophy, (c) Islamic values.

\section{REFERENCES}

Altenburg, Tilman, \& Pegels, Anna. (2012). Sustainability-oriented innovation systemsmanaging the green transformation. Innovation and Development, 2(1), 5-22.

Bariah, Oyoh. (2018). OB CHILDREN PROTECTION IN THE ISLAMIC LAW PERSPECTIVES. Al Mashalih-Journal Of Islamic Law, 1(2), 15.

Campbell, Al. (2021). Evaluating Against a Multi-Dimensional Economic Goal: A Sustainable and Prosperous Socialism. International Journal of Cuban Studies, 13(1), 105-126.

Cooke, Steven J., Hogan, Zeb S., Butcher, Paul A., Stokesbury, Michael J. W., Raghavan, Rajeev, Gallagher, Austin J., Hammerschlag, Neil, \& Danylchuk, Andy J. (2016). Angling for endangered fish: conservation problem or conservation action? Fish and Fisheries, 17(1), 249-265.

Cooper, Elizabeth B. (2019). The Appearance of Professionalism. Fla. L. Rev., 71, 1.

Dominguez, Pablo, \& Benessaiah, Nejm. (2017). Multi-agentive transformations of rural livelihoods in mountain ICCAs: The case of the decline of community-based management of natural resources in the Mesioui agdals (Morocco). Quaternary International, 437, 165-175.

Harwell, Emily E. (2011). Six The Social Life of Boundaries: Competing Territorial Claims and Conservation Planning in the Danau Sentarum Wildlife Reserve, West Kalimantan, Indonesia. In Beyond the Sacred Forest (pp. 180-215). Duke University Press.

Hashim, Ahmed S. (2014). The Islamic State: From al-Qaeda Affiliate to Caliphate. Middle East Policy, 21(4), 69-83.

Lacasse, Richard Marc, Lambert, Berthe, \& Khan, Nida. (2017). Blockchain technologyArsenal for a Shariah-compliant financial ecosystem. Journal of Business and Economics.

McClanahan, Tim, Allison, Edward H., \& Cinner, Joshua E. (2015). Managing fisheries for human and food security. Fish and Fisheries, 16(1), 78-103.

Meadows, Dennis, \& Randers, Jorgan. (2012). The limits to growth: the 30-year update. Routledge. 
Mutti, Diana, Yakovleva, Natalia, Vazquez-Brust, Diego, \& Di Marco, Martín H. (2012). Corporate social responsibility in the mining industry: Perspectives from stakeholder groups in Argentina. Resources Policy, 37(2), 212-222.

Shue, Henry. (2014). Climate justice: Vulnerability and protection. Oxford University Press, USA.

van Huis, Arnold, \& Oonincx, Dennis G. A. B. (2017). The environmental sustainability of insects as food and feed. A review. Agronomy for Sustainable Development, $37(5), 1-14$.

Weiss, Joseph W. (2021). Business ethics: A stakeholder and issues management approach. Berrett-Koehler Publishers.

Yousfi, Hèla. (2014). Rethinking hybridity in postcolonial contexts: What changes and what persists? The Tunisian case of Poulina's managers. Organization Studies, 35(3), 393-421. 